\title{
Missionary diaconate: Hope for migrated people
}

\section{Hannes (JJ) Knoetze ${ }^{1}$}

\begin{abstract}
This paper will discuss migration from a missional diaconate ministry with specific focus on koinonia and the importance thereof for the Kingdom, church and society. The point of departure being that migration is not a foreign concept to the Bible or Christianity. From the earliest days in the Old Testament and throughout the Bible, believers in the Trinitarian God are described as "strangers in this world" (1 Peter). The paper will focus on the concepts of kyrugma/mission, diaconia and koinonia, as the three dimensions of mission (Kritzinger 1998:34-36) and the relation between them. Lastly, the missionary deaconate as a ministry of hope is discussed.
\end{abstract}

Keywords: Migration, missionary diaconate, kyrugma/mission, diaconia, koinonia, hope

\section{Introduction}

Migration is accepted as a part of life and as a solution to negative circumstances. Although there are many positive attributes to migration, migration is the result of negatives, people in search for "something better". Migration may even lead to more negative experiences, especially in a social $^{2}$, economic and emotional way. It brings people's needs to the local congregation's doorstep and in many instances, congregations ignore the need of those who are not (yet) part of the congregation in their community. The problem is: How does the local church help migrating people to come home in a foreign land? And how does the local church help migrated people to live with hope through their negative circumstances?

The hypothesis of this article is that the church's diaconal ministry is focussed mainly on those who are part of the congregation. A plea will be made for a missionary diaconate that understands that diaconia should focus also on those who are not (yet) part of us. Missionary diaconate differs from the deeds of mercy and from NGO's in the sense that it strives to build relationships and help people feel at home because they share our koinonia. "We proclaim to you what we have seen and heard, so that you may also have fellowship (koinonia) with us. And our fellowship (koinonia) is with the Father and with his Son, Jesus Christ" (1 John 1:3). The motivation for missionary diaconate is to glorify God (leitourgia) by taking care of His

1 Hannes Knoetze lecturers at the Department of Theology at the Mafikeng Campus of the North West University, in South Africa. He can be contacted at Johannes.Knoetze@nwu.ac.za

2 Think of the xenophobia situation in South Africa. 
creation. The unconditional link between mission, diaconia and koinonia will be discussed.

The way in which society and the faith community will look at migration and the way that people will experience it, will depend on our ecclesiology $^{3}$ and our view of humanity. Erickson (1992:164-165) named three different views on humanity: humans as machines ${ }^{4}$, humans as animals $s^{5}$ and humans as pawns of the universe ${ }^{6}$ - all of which impacts our views on migrating people. Our understanding of ourselves and of humanity might even give us insight in the reasons for migration. The view of this paper is "that humanity is to be understood as having originated not through a chance process of evolution, but through a conscious, purposeful act by God" (Erickson 1992:165). Secondly, that the image of God is intrinsic to humankind and that we will not be human without it.

\section{Migration, mission and the Church}

Migration and mission, making God known to the world, is inseparably intertwined throughout the Bible. It started with God's covenant with Abram: "The Lord had said to Abram, 'Leave your country, your people and your father's household and go to the land I will show you"' (Gen. 12:1). God's initiative is primary. God binds himself to a human being, a stranger from a foreign land. Throughout the Old Testament God uses the migration of Israel to make Himself known to the nations (Wright 2006:75-104). God made Himself known through the foreigners, His covenant people, in Egypt and in the Promised Land. This mission continues with the incarnation and ministry of Jesus (Wright 2006:105-135). It is in Christ that God confirms His commitment to people in a unique way. He demonstrated His own love for us when Christ died for us while we were still sinners (Rom. 5:1-8) ${ }^{7}$, or foreigners. With the coming of the Spirit and the establishment of the Church in the New Testament (Green 1970), this truth acquired validity. God lives in people. They are His temples (1 Cor. 3:16) and they are strangers in this world

3 It is not in the specs of this article to look at ecclesiology, but it is worth noticing the fact "...that most ecclesiological thinking and even experimenting has taken place within the confines of classical Christendom..." (Kärkkäinen 2002:9)

4 This perspective on humans is interested only in what they can do, their strength, energy and skills. This view of humanity is closely linked to economic values.

5 In this view there is no difference between human beings and other animals. The only difference is one of degree. This view is most fully developed in behaviouristic psychology.

6 This view portrays the idea that humans are at the mercy of worldly forces which control their destiny but have no real concern for them.

$7 \dot{\alpha} \mu \alpha \rho \tau \omega \lambda$ ó $\varsigma$ may refer to persons who were irreligious in the sense of having no concern for observing the details of the Law. Such people were often treated as social outcasts (Louw \& Nida Vol 1, 1993:774). 
(1 Pet. $1: 1){ }^{8}$ What was started in the covenant is decisively continued in Christ and the work of the Spirit in and through the Church. God is the God who "migrated" from heaven to this earth through the incarnation of His Son Jesus Christ (Phil. 2:6-11) and the giving of His Holy Spirit.

When God made a covenant with Abram, the purpose of the covenant was that "all peoples on earth will be blessed through you" (Gen. 12:3b). People will be blessed because they come to know God as the only God. Through His covenant God wants to become known to a person and his descendants, not only for their sake, but by means of them. This promise is quoted by Peter in Acts 3:25 with reference to his Jewish listeners, Abram's physical descendants. And in Gal. 3:8, Paul quoted the same promise to his Gentile listeners, Abram's spiritual descendants. The nations, those who do not (yet) know, love and serve God, are His goal.

In view of the above we may say that migration is part of God's mission to make Himself known to the world. The relational dealings of God with man and creation are given a covenantal character. This is much more than a free relationship. In the covenant, God wants to say to man that His dealings with creation, man included, are dealings directed at the salvation of creation and migration is part of this. Biblically speaking, we must be positive about migration regardless the circumstances ${ }^{9}$ because circumstances don't define people. God's relationship, His commitment to humans defines us. From the perspective of the covenant and mission, it might be possible to say that migration is the way in which God makes Himself known. Therefore the church is a migrating movement; we live with the hope of a new life and a new earth, an eschatological hope.

Looking at migration from a socio-economic or earthly perspective, we are confronted with the negative circumstances: poverty; discrimination; racism; etcetera. From this perspective, migration is not viewed in a positive way. Migrating people, especially in Africa and South Africa are usually people in need, looking for a "new" beginning, looking for hope. My conviction is that we cannot talk about migration from one perspective only, either from the Word or from society. To bring hope to migrated people we must be Word-centred, community-centred and contextual-centred. We must be God-centred, Christian/Kingdom-centred, and society-centred.

In this paper migration is understood in the widest sense of the word. Migration includes physical, spiritual and even emotional migration. Migration is usually closely linked to unhappiness with circumstances or a

8 Van Rensburg (1993:1946, 1950) mentions that the stranger-status of the first readers could indicate their political status- that they were without civil rights in the countries where they were living because they were aliens. For instance, they had no right to property and they fall prey to injustice and discrimination.

9 Whenever people migrated, the circumstances are the defining factor. Israel migrated from Egypt because they were slaves. In Acts 8:1 the believers were scattered because of the persecution. 
specific calling or conviction. Whenever migration is discussed, it always involves socio-, economic-, and/or political circumstances. In some instances migration might happen because of religious or spiritual reasons.

At an information session of Afriforum (21-02-2001), it was made known that about $40 \%$ of foreign job opportunities of South Africans fail. In many of the cases, the local workforce was negative about foreign colleagues. About $80 \%$ of migration is unsuccessful as a result of family problems.

Freier $(2010)^{10}$ highlights the lack of reliable data on migration, especially in Africa and makes the following observations:

- In most developing African countries, migration and development are seen as separate policy issues.

- The ostensible links between migrants and crime, HIV/AIDS and unemployment are academically unfounded. ${ }^{11}$

- Local government is encouraged to ensure access to markets, accommodation and critical social services for all city residents to avoid economic exclusion, resulting in the loss of migrant investments.

- Conventional theories, which see rural-urban migration as unidirectional urbanisation, are challenged. It is shown that urban households are increasingly dependent on food transfers from rural areas.

The above mentioned observations might as well be true of the Church, because we don't look at migration from a theological perspective. Sometimes the Church forgets that we ourselves are migrated people who live by the grace of God. Therefore we do not see the opportunities that migrating people have to offer in the building of the Kingdom. We usually only see migrated people as a threat to us and our environment.

Spiritually, people also migrate inwards or between denominations and even between faiths when migrated people are experienced as a social-, economic-, and political threat. ${ }^{12}$ The last theological study relating the influences of population, migration and mission within the South African context was done by Kritzinger (1988). In this study he describes the context in typical South African scenarios, which are still applicable today. Kritzinger (1988:95-116) ends his study with three topics related to this paper: The incomplete evangelical task; the incomplete social calling and the incomplete Church. These three topics will be discussed in this paper as kyrugma/mission, diaconia and koinonia, which are the three dimensions of mission (Kritzinger 1988:34-36). However, mission will be incomplete if it

${ }^{10}$ In his book review on Jonathan Crush and Bruce Frayne (2010).

11 There are however academic studies especially on the impact of migration on spreading HIV and Aids. The combination of HIV and AIDS and economic migration in Southern Africa is causing serious depletion of human resources (Morris \& Lewis, 2003:8).

12 Examples are: 1986 the establishment of the APK after "Kerk en Samelewing" and the unresolved issues about the Belhar Confession within the Dutch Reformed Church family in South Africa. Or the rapid growth in the AIC's mainly from the mainline churches. 
does not lead to worship (leitourgia). Wright (2006:133) quoted Piper: "Mission is not the ultimate goal of the church. Worship is. Mission exists because worship doesn't".

\section{Missional or missionary diaconate: Terminology}

\section{Missional or missionary}

Missiologists have wonderful definitions of mission, but regardless of our definitions, the people understand mission ${ }^{13}$ in general as: "(a) Propagation of faith; (b) expansion of the reign of God; (c) conversion of the heathen and (d) the founding of new churches" (Bosch 1991:1).

Mission is under a lot of criticism (Bosch 1991:2, Saayman 2010) and we want to save it through better definitions and altered terminology. ${ }^{14}$ This might be one of the reasons to change from missionary to missional. Saayman (2010:5) argues that the term "missional" as an adjective, linked to "missional church", has established itself in missiological discourse in the last decade of the twentieth century. It was mainly a term utilised in the First World, especially in North America and Europe. But towards the end of the first decade in the twenty-first century, it has established itself also in the Third World, especially in South Africa. Saayman (2010:9) continues to show that both the terms "missionary" and "missional" originated from the missio Dei. ${ }^{15}$ When Saayman (2010:10-12) tries to differentiate between the two terms he identifies the following three areas: The first distinctive area is the context within which the term missional originated - specifically Western, North Atlantic, emerging postmodern culture. The second distinctive area is found in the aim or vision of the utilisers of this term, which, among other things, includes the question of the identity of the church and its social relevance in its existing context. The third distinctive area is the relationship to and interaction with the emergent church or emerging church movement. ${ }^{16}$

For my own understanding we are back at the old distinction of mission, which is understood as centripetal in the Old Testament, and as centrifugal

13 "The term mission and missionary as it is generally understood today in Theology, namely as describing the spread of the Christian faith among unbelievers, has a very chequered history" Saayman (2010:6-7).

${ }^{14}$ Because of the negative perceptions and connotations to mission and missionary, Saayman (2010:7) shows how it became fashionable to talk about inter-church aid and fraternal workers.

${ }^{15}$ Mission is understood as ultimately proceeding from a Trinitarian God. The ecclesiology functioning in this backdrop is an understanding that God the Father, through the redemption of the Son and the empowerment of the Holy Spirit, sent the church. The classical formulation of missio Dei affirms that mission is God's way of sending forth (See Bosch 1991:389-393).

${ }^{16}$ For reflections on missional ecclesiology (in South Africa) see Niemandt (2010:397-412) 
in the New Testament. Missional can then be understood as centripetal, because we want to be a blessing to the community in which we live by our way of living (Wright 2006:24-25). In this sense we live missional reaching out to our own people and those who come to us for help. Missionary can be understood as being centrifugal - going out not only to our own community but also to other communities. Both centripetal and centrifugal have certain shortcomings and misinterpretations, in the same way that both missional and missionary have some shortcomings and misinterpretations. Therefore I don't think it is an either or but both: missional and missionary. The preferred term will be contextually defined.

Bosch (1991:2) clearly shows that criticism of mission should in itself not be a surprise. We tend to forget that we are propagating change and change always leads to criticism and even conflict. This unfortunate situation is the result of our separation between the different ministries within the church. We have done mission work and diaconia without, or totally separate, from koinonia. I believe that if we take the koinonia seriously, this false differentiation between missional and missionary will disappear.

The problem is that we distinguish and separate the ministries of the Church from its identity. We cannot talk about mission without talking about ecclesiology. The Church is both the fruit of God's mission - those whom He has redeemed, and the agent of His mission - the community through which $\mathrm{He}$ acts for the world's redemption (Williams 2004:85). "There is Church because there is mission, not vice versa" (Bosch 1991:390). Migration is all about change, about being on a "mission" for a better life. It is by looking for a better life that the missio Dei and the "mission" of man meet and that the Agogic perspective of the Church as a sphere of change forms an essential part in the bringing of hope (Nel 2000:21-25).

In theology, change can only be understood pneumatologically. This Agogic moment propels all ministries, but we experience this theology especially in the ministry to people who are in any case changing and who experience change dramatically and sometimes traumatically. It is only through a pneumatological ${ }^{17}$ understanding of change, or more specifically an understanding of the missio Trinitatis Dei, that we can bring hope. Therefore the essence of the Church, of the koinonia, is to be a missionary community. Greenwood (1996:28) asked: "What is mission if not the engagement with God in the entire enterprise of bringing the whole of creation to its intended destiny? A local church cannot claim to be part of this if it only serves itself."

${ }^{17}$ In the Nicene Creed we confess: "I believe in the Holy Spirit, the Lord and Giver of Life; who proceeds from the Father, and the Son; who with the Father and the Son together is worshipped and glorified;..." 
If mission is conceptualised only as missional or missionary, will it bring hope for migrated people?

\section{Diaconia $^{18}$}

Diaconia/diaconeo $=$ "to render assistance or help by performing certain duties, often of a humble or menial nature" (Louw \& Nida 1993:460).

It seems that migration is one of the main reasons that Noordegraaf (1991:9) ${ }^{19}$ mentioned for the necessity to reinterpret the diaconate as "dienend getuigen" 20 or missionary diaconate. The problem with most of the diaconal studies is that the focus of the studies fall mainly on the faith community because the diaconia come from the faith community. This leads, firstly, to the thinking of many Christians that it is the responsibility of the Government to take care of the society and the Church has no responsibility to make a difference, regardless of the purpose of the Covenant. Secondly, the lack of vision for the diaconia in the Kingdom of God hinders it to make a difference in this world because there is an inherent fear for koinonia. Fear that "they" will want to become one of us and share in our privileges. When diaconia is used in the sense of crossing borders, it must be understood as "dienend getuigen" or missionary diaconate.

In many instances the Church's thinking about diaconia is the same as that of the Greeks who think that diaconia is unworthy. According to Bromiley (1985:152) “...we are born to rule not to serve. Service acquires value only when it promotes individual development, or the development of the whole as service of the state. ...the idea of self-sacrificial service finds little place". In the Septuagint we seldom find the word diaconein. We find other words that are translated with "service". For this reason the source of the diaconeo word group, as found in the New Testament, must not be sought at the Greeks or the Jews. Jesus filled it with a specific content. "By exalting service and relating it to the love of God, Jesus both sets forth a completely different view from that of the Greeks and purifies the Jewish concept" (Bromiley 1985:153). If we want to bring hope we must follow in the footsteps of Jesus and relate our diaconia to the love of God. Our motivation for diaconia, Word-centeredness, is the distinction between us and other role players working in the community.

Through the directive in John 12:26, Jesus proclaims to the people what it entails to serve Him. This is a general prescription that is valid for every believer and due to the accumulation of the diacon word group this can be viewed as a definition of what it means to be a diaconos of Jesus Christ. The opinion that diaconia primarily describes the work of service of people with a

\footnotetext{
${ }^{18}$ For more comprehensive arguments compare Knoetze (2002:49-77).

${ }^{19} \mathrm{He}$ does not refer to migration specifically but to the circumstances that cause migration like socio-economical influences, one worldwide economy and from Christianity the role of the ecumenical movement.

${ }^{20}$ Service and witness
} 
specific calling in offices of the Church, is questionable based on Jesus' definition of diaconia. It is clear that the author of the Gospel of John was of the conviction that every person who follows Jesus should also be a diaconos (Breed 2011:3). From John 12 Breed (2011) states it is clear that to follow Christ you must come to the decision to glorify the Father by fulfilling the task given by Him, even if this could mean your death. The main purpose of diaconia is then to glorify God. It seems that this purpose of diaconia, glorifying God by fulfilling the task given by the Father, is in reality far from the local church's understanding of diaconia. Our diaconia is more often than not people- centred- focussing only on deeds of compassion and asset-basedfocussing only on what we have physically and it is not God-centredproclaiming the Word and including deeds of faith.

In His diaconia, his death, Jesus reveals the love of God and through this He conquers sin and Satan. This is the Gospel according to John. To be obedient to Jesus and to follow Christ is life to the full (John 10:10). This is the Word that has been proclaimed by the Father, through Jesus, to all people: "For God so loved the world that he gave his only begotten Son, that whosoever believeth in him should not perish, but have everlasting life" (John 3:16). In John 12 and elsewhere Jesus repeatedly refers to the Father who had sent him, the missio Dei. Jesus also refers to Himself as a diaconos (Mark 10:45, John 13). In John 17 Jesus describes the content of the faith of the disciples by saying that they are the ones who believe that the Father had sent Him. The aim of Jesus' diaconia is to attract all to Him, the koinonia. "In John's description of the Gospel the emphasis is on relationships" (Breed 2011:6). Diaconia is closely linked to love for God and God's children and those who are not (yet) children of God (John 17:18-20).

Breed (2011:7) argues that diaconia cannot be separated from the humble and sacrificial love service of Jesus as described in John 13 and the directives to Peter in John 21:15-22. In Peter's case this means to take care of the flock of the Lord (John 21:15-22), but Jesus also clearly says that it can mean something else to another diaconos - John (John 21:20-22). The implication for the diaconia of the Church is that we must focus on relationships, or koinonia. First our koinonia with the Trinitarian God, but also our koinonia in the Church and koinonia with the world, those who are not (yet) part of the Church.

\section{Koinonia}

Koinonia $=$ "an association involving close mutual relations and involvement" (Louw \& Nida 1993:446)

Koinoneo $=$ "to share one's possessions, with the implication of some kind of joint participation and mutual interest. That which is readily shared 'willing gift, ready contribution"” (Louw \& Nida 1993:569). 


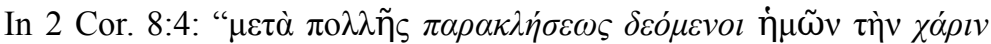

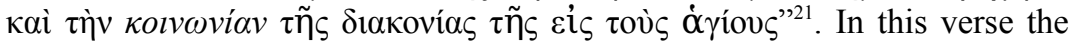

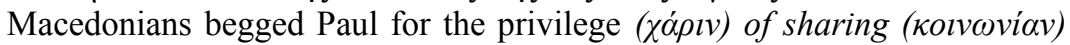

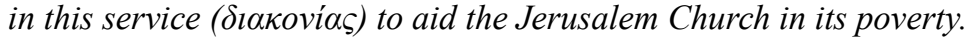

According to Martin (1986:254), koinonia signifies the notion of having a share in fellowship in work which is in this case the diaconia of the collection. The key words in this passage are: garis; koinonia and diaconia. In this sense koinonia conveys the idea of participation in the objective reality, the religious good. It is clear then that kiononia is more than mere fellowship. Koinonia and diaconia are an integral part of each other. There can be no real diaconia without koinonia and no koinonia without diaconia. We can distinguish between them but we cannot separate them.

Burger (1999:231-245) explains that with koinonia, it is about people who give recognition to each other, who care for each other, who take responsibility for each other and who learn to love each other. We must love in the same manner as Jesus and the Father loved us. We cannot only love the people who love us back, our love must incorporate more. Three specific groups that challenge our love are named in the Bible: The strangers or foreigners (Gen 18:1-15; Heb. 13:2); the vulnerable - people that don't belong (Matt 25:31) and our enemies (Matt 5:42-47). Migrated people belong to either one of these groups. Migrated people challenge our love. If the local church just wants to help them by doing some deeds of mercy and we are not prepared to have koinonia with them and let them become part of our community, we won't bring them any hope. Hope is not to be found in material things, which can help, but real hope is found in relationships, in koinonia. Do we want to get involved with them?

\section{The Hope}

"(But) have reverence for Christ in your hearts, and honour him as Lord. Be ready at all times to answer anyone who asks us to explain the hope you have in you" (1 Pet. 3:15).

When we talk about hope, the truths of recreation; resurrection and eschatology, help us in our understanding of the hope that lives within us (Botman 2002). The faith community is a community of hope formed by these truths and because they want to be a blessing to migrating people, they share this hope through koinonia. This relationship is built through a missionary diaconate ministry.

\section{The truth of Recreation- a new life.}

Migrating people are looking for a new beginning, a new life. The story of the Bible is the story of creation and recreation. Throughout the Bible we read

${ }^{21} 2$ Cor. 8:4 "They begged us and pleaded for the privilege of having a part in helping God's people in Judea." 
about new beginnings (Gen. 6, 12, Ezek. 36:26) and the promise of redemption. In the New Testament we are called to be born again (John 3). This proclamation is founded in Jesus Christ as the "new Human Being" and "when anyone is joined to Christ, he is a new being; the old is gone, the new has come" ( 2 Cor. 5:17). The New Testament talks of the new creation, the new heaven and the new earth, and the church is part of this new creation. But the church also takes part in this new creation; it alerts us to the fact that God is doing new things among us, with us and through us in our history. The newness is the Gospel, the Word of God. God creates through His Word (John $1: 1-4)$ a new community of faith. Therefore, the Gospel is recreating a new reality of koinonia. Recreation calls the Christian to a special nurturing task as a responsible citizen of the Kingdom as well as of the state.

The Church needs to fulfil its priestly ministry of kyrugma and diaconia in creating new life possibilities for migrated people. This new life is only to be found in new relations with God, with my neighbour and with myself. It is the privilege of the Church to assist in the creation of possibilities for new relationships with God through preaching the Word and living the Word, by being the body of Christ, especially to strangers and vulnerable people. The Church must take part in creating new possibilities for the relationship with my neighbour; making participation in the economic life possible and in the formation of networks, partnerships and jobs. The Church can help to create a new possibility for the relationship with the self, hereby reinforcing the image of God in individuals and proclaiming the love of God to them.

\section{The truth of the resurrection.}

The resurrection of Jesus Christ is the essence, not only for Christian doctrine, but for the Christian life. 1 Cor. 15 states clearly that if the resurrection did not happen, our Christian faith is false and the Christian life a lie. Therefore, the resurrection is central to Christianity and the Christian life. McCledon (1988) identified the following crucial propositions of the resurrection: Resurrection is the vindication of justice; resurrection is a new way of construing the world and resurrection is the ultimate transformation. These propositions determine the content of the missionary diaconate as a ministry to migrating people.

The Church needs to fulfil its kingly function by working actively against the negative causes associated with migration. The new dispensation is confirmed by the resurrection of Christ. Since the Church has the privilege to take part in the missio Dei, it is our duty to preach good news to the poor; proclaim freedom to the prisoners; help the blind to recover their sight; take part in releasing the oppressed and to proclaim the grace of the Lord (Luke 4:18-19; Matt 25). Resurrection is not a pie in the sky, it is a 
reality. We must live it. The koinonia, with the resurrected Christ, is the reality that determines our lives.

\section{The truth of Eschatology.}

The resurrection cannot stand alone; we have to go beyond it to embrace the eschatological reality. According to Botman (2002), “...the nature of true eschatological ethics is in living 'as if the status quo is not' and in the assumption that the time is short and that the scheme or form of the world is passing by". Therefore, any theology that says "no" to the status quo, must simultaneously shout "yes" for the new creation that is becoming a visible reality in our midst. "Transformative living is living in the presence of the future inaugurated by Jesus Christ" (Botman 2002). John 17:3 teaches us that this eschatological reality is also a relational reality; a knowing of God and the One that was sent by Him.

The Church needs to fulfil its prophetic function by working actively according to the eschatological reality; proclaiming the will of God for a time like this and by living our responsibility in a situation of migration. In this world, the Church must live as foreigners who are migrating to a new world.

\section{The Church as a Sphere of Hope}

The migrating people are in many instances like the men who walked from Jerusalem to Emmaus after Easter weekend (Luke 24): "We have hoped..." they said. They have not lost all hope, but the little that was left, has been crushed by the facts, by circumstances and by the realities. They have become realists who are satisfied to live with minimal hope. Jesus joined them and $\mathrm{He}$ did not leave until they had seen hope again. Real hope cannot be read from papers or statistics; it takes people who can see the resurrection.

In many instances, we, the Church also become realists who are satisfied to live with minimal hope. Hope that is lost leaves a vacuum that one must fill. Some fill it with cynicism. According to the world, the Church filled it with dogma and confessions. Botman (2002) argues that people are changed, not by ethical urging but by transformed imagination. Transformed imagination in this instance must be understood as the development of an imagination of hope. We need a ministry of missionary diaconate which can see God's presence in the predicament and the hand of God in the creation of hope against all hopelessness. We need a ministry that provokes new realities of koinonia in communities and gives birth to new actions in society because it has learnt that God is busy with renewal on this continent. The Church has to understand that when the words one, holy, catholic and apostolic refer to the nature of the Church, they have to be visible qualities of the Church as it actually exists. Because the only way we can measure a church, is by what we can see (Van Engen 2004:60-65). There must be a 
movement and development from our conception of what the church is, towards our commitment to what the Church must become (Moltmann 1977:2). Looking at the above mentioned three truths, we cannot think of the church only inwardly, we must think of the church in reference to the world. Moltmann (1977:341) calls for a radical missional response: "The church's unity is its unity in freedom. The church's holiness is its holiness in poverty. The church's apostolicity bears a sign of the cross and its catholicity is linked with its partisan support for the oppressed".

\section{References}

Amanze, J.N. 2009 Paradigm Shift in Theological Education in Southern and Central Africa and its Relevance to Ministerial Formation. World Council of Churches

Bosch, D.J. 1991. Transforming mission: Paradigm shifts in theology of mission. Maryknoll, New York: Orbis Books

Botman H.R. 2002. Mission from the African soil. (Address delivered at the Service and Witness conference of the Dutch Reformed Family in Africa at Stellenbosch in 2002). (Unpublished)

Breed, G. 2011. The daikon-word group in John 12:26. (Not yet published)

Bromiley, G.W. 1985. Theological Dictionary of the New Testament. Grand Rapids: B. Eerdmans

Burger, C. 1999. Gemeentes in die kragveld van die Gees. Bloemfontein: CLF Drukkers.

Erickson, M.J. 1992. Christian Doctrine. 2nd edition. USA: Baker Book House.

Freier, L.F. 2010. Book review on, Chrush, J \& Frayne, B (eds). 2010. Surviving on the move: migration, poverty and development in southern Africa. In Politeia Vol 29 No 32010 @ Unisa Press pp 107-109

Green, M. 1970. Evangelism in the early Church. 1978 edition. London: Hodder and Stoughton.

Kärkkäinen, V. 2002. An introduction to ecclesiology. Downers Grove: InterVarsity Press.

Knoetze, J.J. 2002. Teologiese motiewe vir 'n missionêr diakonale bediening van die kerk. DD. Thesis, University of Pretoria, Pretoria.

Kritzinger, J.J. 1988. Die onvoltooide sendingtaak in Suid Afrika. Pretoria: Pro Media Publikasies.

Louw, J.P. \& Nida, E.A. 1993. Greek English Lexicon of the New Testament. New York: United Bible Societies.

Martin, R.P. 1986. World Biblical Commentary 2 Corinthians. Waco, Texas: Word Books Publisher.

Moltmann, J. 1977. The Church in the power of the Spirit. London: SCM Press

Morris, J.T. \& Lewis, S. 2003. United Nations mission report: Lesotho, Malawi, Zambia and Zimbabwe. Rome 
Nel, M. 2000. Youth Ministry. An inclusive congregational approach. Pretoria: Design Books.

Niemandt, C.J.P. 2010. Five years of missional church: Reflections on missional ecclesiology. Missionalia 38(3) November 2010: 397-412.

Noordegraaf, A. 1991. Oriëntatie in het diakonaat. Zoetemeer: Uitgeverij Boekencentrum

Saayman, W. 2010. Missionary or missional? A study in terminology. Missionalia 38(1) April 2010: 5-16.

Van Engen, C. 2004. God's missionary people. Grand Rapids: Baker Books

Van Rensburg, F.J. 1993. 1 Petrus, in Die Bybel in Praktyk, edited by Vosloo \& Van Rensburg 1993:1944-1958.

Vosloo, W. \& Van Rensburg F.J. 1993. Die Bybel in Praktyk. Vereeniging: Christelike Uitgewersmaatskappy.

Williams, R. 2004. Mission-shaped church. Church planting and fresh expressions of church in a changing context. London: Church House Publishing.

Wright, C.J.H. 2006. The mission of God. USA: Intervarsity Press. 